\title{
KAJIAN KELAYAKAN DESTINASI WISATA UNTUK MEWUJUDKAN PARIWISATA KELAS DUNIA (Studi pada Kecamatan Sidamulih Kabupaten Pangandaran Provinsi Jawa Barat)
}

\author{
Oleh
}

\author{
Budi Margono, Riswati
}

Institut Pemerintahan Dalam Negeri

margonobudi07@gmail.com

\begin{abstract}
$T$

is study aims to determine the extent to which tourist destinations in Sidamulih sub-district can contribute to the realization of Pangandaran Regency into world-class tourist visits, Pangandaran Regency has a vision and mission, to make a world-class tourist destination. Pangandaran Regency, is one of the districts in Indonesia which has very beautiful natural resources, and has various very specific tourist destinations, including coastal tourism destinations, natural tourism destinations and culinary tourism destinations as well as cultural and religious tourism destinations, all of which are supported by culture people in Pangandaran Regency who have a polite and friendly culture, this study uses descriptive qualitative methods with an inductive approach, where the conclusion of the results of this study is, currently the management of tourist destinations in several districts, which are in Pangandaran Regency, especially Sidamulih district, is doing clean up, to make tourist destinations in Sidamulih District, a destination that should be visited by foreign tourists and domestic tourists. Local products in the Sidamulih sub-district are very supportive and the local community is very humanist and friendly when visited, making tourists feel at home to linger enjoying various tourist destinations in Sidamulih sub-district.
\end{abstract}

Keywords: feasibility study, tourist destinations, and world-class tours.

\begin{abstract}
AbSTRAK
$\mathrm{P}$ enelitian ini bertujuan untuk mengetahui sejauh mana destinasi wisata pada Kecamatan Sidamulih dapat memberikan kontribusi terwujudnya Kabupaten Pangandaran menjadi kunjungan wisata berkelas dunia, Kabupaten Pangandaran memiliki visi dan misi, untuk menjadikan destinasi wisata berkelas dunia. Kabupaten Pangandaran, merupakan salah satu kabupaten di Indonesia yang memiliki sumber daya alam yang sangat indah, dan memiliki berbagai destinasi wisata yang sangat specifik, meliputi destinasi wisata pantai, destinasi wisata alam dan destinasi wisata kuliner, serta destinasi wisata budaya dan religius, semua ini ditopang oleh budaya masyarakat di Kabupaten Pangandaran yang memiliki budaya santun dan bersahabat, penelitian ini menggunakan metode kualitatif deskriptif dengan pendekatan induktif, di mana simpulan dari hasil penelitian ini adalah, saat ini pengelolaan destinasi wisata di beberapa kecamatan, yang berada di Kabupaten Pangandaran, khususnya Kecamatan Sidamulih, sedang melakukan berbenah diri, untuk menjadikan destinasi wisata di Kecamatan Sidamulih, menjadi destinasi yang patut dikunjungi oleh para wisatawan mancanegara dan wisatawan dalam negeri. Produk-produk lokal di Kecamatan Sidamulih sangat mendukung
\end{abstract}


dan masyarakat setempat sangat humanis dan bersahabat jika dikunjungi, membuat para wisatawan betah untuk berlama-lama menikmati berbagai destinasi wisata yang berada di Kecamatan Sidamulih.

Kata kunci: studi kelayakan, destinasi wisata, dan pariwisata kelas dunia.

\section{PENDAHULUAN}

$\mathrm{I}$ ndonesia merupakan negara kepulauan yang terletak pada garis katulistiwa serta memiliki dua musim yaitu musim hujan dan kemarau berbeda dengan negara lain yang memiliki empat musim, keadaan alam yang subur di mana potensi sumber daya alam berupa hutan, gunung, sungai, laut dan lainnya sangat memesona, sehingga Indonesia mendapatkan julukan jambrut khatulistiwa. Potensi sumber daya alam dan keindahan yang menciptakan berbagai destinasi wisata yang wajib dikunjungi oleh para wisatawan mancanegara maupun wisatawan dalam negeri. Keanekaragaman alam, flora, fauna serta karya cipta manusia yang memiliki nilai artistik untuk dikembangkan menjadi sebuah usaha di bidang kepariwisataan. Indonesia sebagai salah satu negara kepulauan dan maritim tentunya memiliki perairan yang sangat banyak. Kondisi tanah yang subur menjadikan Indonesia sebagai pusat perhatian kelompok manusia untuk menetap dan mengembangkan usahanya masing-masing, sedangkan potensi perairan yang berupa lautan dan pantai merupakan salah satu objek wisata yang banyak digemari oleh wisatawan Nusantara maupun wisatawan mancanegara. Hal ini dikarenakan Indonesia merupakan negara tropis yang memiliki air laut yang jernih yang dapat dimanfaatkan sebagai kegiatan di bidang pariwisata.

Salah satu objek destinasi wisata alam di Jawa barat yang wajib dikunjungi adalah destinasi wisata di Kabupaten Pangandaran, di mana Pangandaran memiliki berbagai jenis destinasi yang sangat menakjubkan dan sangat indah, misalnya wisata pantai Pangandaran, wisata alam dengan berbagai tanaman di perbukitan Pangandaran, wisata kuliner dengan berbagai citarasa, wisata budaya, wisata religius serta wisata goa nan memesona, semua ini memberikan sensasi keindahan tersendiri bagi para pelancong wisatawan yang berkunjung ke Pangandaran

Destinasi wisata Pangandaran merupakan destinasiyangoleh pemerintah masuk ke dalam program sebagai kunjungan destinasi wisata yang akan diberdayakan dan dikembangkan menjadi destinasi wisata berkelas dunia, setelah Pulau Bali dan destinasi di Lombok dan Labuanbajo di Provinsi NTT, yang terkenal dengan Komodo-nya.

Salah satu kendala yang sering dihadapi industri pariwisata, pada umumnya adalah rendahnya aksesibilitas terhadap berbagai sumber produktif termasuk informasi dan pelayanan teknologi. Rendahnya aksesibilitas berimplikasi pada pemborosan penggunaan seluruh sumber daya yang ada dan dapat menimbulkan kerancuan. Bahkan kebingungan di antara industri pariwisata sendiri atas program pembinaan yang ada. Oleh karena itu diperlukan langkahlangkah konkret dalam upaya percepatan peningkatan aksesibilitas industri pariwisata terhadap sumber daya produktif, termasuk pelayanan informasi, dan teknologi, sangat penting untuk segera di wujudkan agar keberadaan destinasi mudah diakses.

Fokus penelitian dilakukan hanya berfokus kepada sejauh mana keberadaan destinasi wisata Pangandaran bisa dikembangkan dan ditingkatkan menjadi destinasi wisata berkelas dunia.

Tujuan penelitian ini adalah ingin mengetahui dan mencari data-data dukung yang akan peneliti jadikan sumber bahan 
studi dan kajian untuk dijadikan sebuah tulisan dalam jurnal ilmiah yang dapat dipublikasikan.

\section{KAJIAN PUSTAKA}

\section{Studi Kelayakan}

Pengertian studi kelayakan adalah kajian yang dilihat dari berbagai segi aspek baik aspek legalitas, aspek teknis, pemasaran, sosial ekonomi maupun manajemen dan keuangan yang hasilnya digunakan untuk mengambil keputusan suatu proyek dijalankan, ditunda, atau tidak dijalankan.

Suatu upaya yang dilakukan oleh individu atau kelompok, sebelum melakukan kegiatan yang akan dilaksanakannya, sehingga mereka perlu melakukan kajiankajian dan analisis analisis terlebih dahulu terhadap potensi yang akan dikerjakan dan manfaat apa dan bagaimana hasil yang akan dicapainya kelak. Ini perlu dilakukan agar seseorang dan kelompok tersebut akan tahu terlebih dahulu apa yang akan dicapai, dan manfaat apa yang akan didapatnya.

Studi kelayakan merupakan proses kegiatan yang dilakukan sekelompok orang atau individu sebelum melakukan sebuah kegiatan usaha, agar secara lebih jelas arah usaha yang akan dikerjakan dan hasil yang akan dicapai pada kemudian hari.

\section{Destinasi Wisata}

Destinasi wisata adalah lokasi wisata, yang akan dikunjungi oleh para wisatawan, yang memiliki daya Tarik, dan keunikan tersendiri, sehingga wisatawan tertarikuntuk berkunjung ke lokasi dimaksud, destinasi wisata biasanya memiliki daya Tarik dan daya pikat lebih, sehingga wisatawan sangat tertarik dan betah berkunjung ke lokasi itu.

Berdasarkan Undang-Undang No. 10 Tahun 2009 tentang Kepariwisataan, daerah tujuan pariwisata yang selanjutnya disebut destinasi pariwisata adalah kawasan geografis yang berada dalam satu atau lebih wilayah administratif yang di dalamnya terdapat daya tarik wisata, fasilitas umum, fasilitas pariwisata, aksesibilitas, serta masyarakat yang saling terkait dan melengkapi terwujudnya kepariwisataan.

Berdasarkan Undang-Undang No. 10 Tahun 2009 tentang Kepariwisataan, Daya Tarik Wisata dijelaskan sebagai segala sesuatu yang memiliki keunikan, kemudahan, dan nilai yang berupa keanekaragaman kekayaan alam, budaya, dan hasil buatan manusia yang menjadi sasaran atau kunjungan wisata. Tujuan wisata yang juga disebut destinasi pariwisata adalah kawasan geografis yang berada dalam satu atau lebih wilayah administrasi yang di dalamnya terdapat daya tarik wisata, fasilitas umum, fasilitas pariwisata, aksesibilitas, serta masyarakat yang saling terkait dan melengkapi terwujudnya kepariwisataan.

Menurut Mariotti dalam Oka A. Yoeti (1996), daerah tujuan wisata harus memiliki hal menarik yang dapat ditawarkan kepada wisatawan. Destinasi pariwisata harus memenuhi tiga syarat berikut ini.

1) Memiliki something to see, yaitu di tempat tersebut harus ada objek dan atraksi wisata khusus, yang berbeda dengan apa yang dimiliki daerah lain untuk dilihat.

2) Menyediakan something to do, yaitu di tempat tersebut harus disediakan fasilitas untuk melakukan kegiatan rekreasi yang dapat membuat nyaman wisatawan

3) Menyediakan something to buy, yaitu tempat tersebut harus tersedia fasilitas untuk berbelanja, terutama oleh-oleh dan barang kerajinan khas yang dapat dibawa pulang ke tempat asal wisatawan.

\section{Pariwisata}

Menurut Aryanto pariwisata diartikan sebagai seluruh kegiatan orang yang melakukan perjalanan kemudian dan tinggal di suatu tempat di luar lingkungan keseharian 
untuk jangka waktu tidak lebih dalam waktu satu tahun dengan tujuan untuk bersantai (lieisure). Dalam kegiatan pariwisata mengandung unsur yang meliputi:

1. Kegiatan perjalanan

2. Bersifat sukarela

3. Hanya untuk sementara

4. Bertujuan untuk menikmati objek dan daya tarik wisata

Produk industri pariwisata meliputi semua jasa yang diberikan oleh berbagai perusahaan semenjak seorang wisatawan meninggalkan kediamannya sampai di tempat tujuan, hingga kembali ke tempat asalnya untuk mengembangkan kepariwisataan alam sebagai suatu industri (Desri, 2010: 7).

Pariwisata berasal dari dua kata, yakni Pari dan Wisata. Pari dapat diartikan sebagai banyak, berkali-kali, berputar-putar atau lengkap. Sedangkan wisata dapat diartikan sebagai perjalanan atau bepergian yang dalam hal ini sinonim dengan kata "travel" dalam bahasa Inggris. Atas dasar itu, maka kata "Pariwisata" dapat diartikan sebagai perjalanan yang dilakukan berkali-kali atau berputar-putar dari suatu tempat ke tempat yang lain, yang dalam bahasa Inggris disebut dengan "Tour". (Yoeti, 1991: 103). Sementara itu, menurut R. G. Soekadijo (1997: 8), Pariwisata ialah segala kegiatan dalam masyarakat yang berhubungan dengan wisatawan.

Indonesia adalah salah satu negara yang memiliki banyak potensi alam baik di daratan maupun di lautan. Keanekaragaman alam, flora, fauna, dan karya cipta manusia yang memiliki nilai jual untuk dikembangkan menjadi sebuah usaha di bidang kepariwisataan. Indonesia sebagai negara maritim memiliki potensi perairan yang sangat melimpah. Kondisi tanah yang subur menjadikan Indonesia sebagai pusat perhatian kelompok manusia untuk menetap dan mengembangkan usahanya masing- masing, sedangkan potensi perairan yang berupa lautan dan pantai merupakan salah satu objek wisata yang banyak digemari oleh wisatawan Nusantara maupun wisatawan mancanegara. Hal ini dikarenakan Indonesia merupakan negara tropis yang memiliki air laut yang jernih yang dapat dimanfaatkan sebagai kegiatan di bidang pariwisata.

Menurut Undang-Undang Kepariwisataan No. 9 Tahun 1990, Pariwisata adalah suatu perjalanan yang dilakukan untuk sementara waktu dari suatu tempat ke tempat lain dengan maksud tidak untuk mencari nafkah di tempat yang dikunjungi tapi hanya semata untuk menikmati perjalanan tersebut untuk mencapai kepuasan. Adanya pariwisata mempunyai banyak manfaat antara lain mengenal karakteristik suatu bangsa yang dikunjungi, mengenal kebudayaan, adat-istiadat dan sekaligus dapat menikmati keindahan alam di negara tersebut. Pariwisata merupakan salah satu hal yang penting bagi suatu negara, terutama pemerintah daerah tempat objek wisata itu berada. Adanya kegiatan pariwisata dapat menambah pemasukan dari pendapatan setiap objek wisata. Indonesia sebagai negara yang berbentuk kepulauan sangat potensial di sektor pariwisata. Pembangunan sektor pariwisata dapat dilakukan dengan memanfaatkan potensi wisata yang beragam di Indonesia. Kondisi alam di setiap daerah Indonesia berbeda-beda, sehingga pengelolaannya pun harus disesuaikan dengan potensi wisata yang ada di daerah tersebut.Menurut Pendit dalam Yuliani (2013), ada beberapa jenis pariwisata yang sudah dikenal, antara lain sebagai berikut.

1) Wisata budaya, yaitu perjalanan yang dilakukan atas dasar keinginan untuk memperluas pandangan hidup seseorang dengan cara mengadakan kunjungan ke tempat lain atau keluar negeri, mempelajari keadaan rakyat, kebiasaan dan adat istiadat mereka, 
cara hidup mereka,kebudayaan dan seni mereka.

2) Wisata kesehatan, yaitu perjalanan wisatawan dengan tujuan untuk menukar keadaan dan lingkungan tempat sehari-hari di mana ia tinggal demi kepentingan beristirahat baginya dalam arti jasmani dan rohani.

3) Wisata olahraga, yaitu wisatawanwisatawan yang melakukan perjalanan dengan tujuan berolahraga atau memang sengaja bermaksud mengambil bagian aktif dalam pesta olahraga di suatu tempat atau negara.

4) Wisata komersial, yaitu termasuk perjalananuntukmengunjungi pameranpameran dan pekan raya yang bersifat komersial, seperti pameran industri, pameran dagang dan sebagainya.

5) Wisata industri, yaitu perjalanan yang dilakukan oleh rombongan pelajar atau mahasiswa, atau orang-orang awam ke suatu kompleks atau daerah perindustrian dengan maksud dan tujuan untuk mengadakan peninjauan atau penelitian.

6) Wisata bahari, yaitu wisata yang banyak dikaitkan dengan danau, pantai atau laut.

7) Wisata cagar alam, yaitu jenis wisata yang biasanya diselenggarakan oleh agen atau biro perjalanan yang mengkhususkan usaha-usaha dengan mengatur wisata ke tempat atau daerah cagar alam, taman lindung, hutan daerah pegunungan dan sebagainya yang kelestariannya dilindungi oleh undangundang.

8) Wisata bulan madu, yaitu suatu penyelenggaraan perjalanan bagi pasangan-pasangan pengantin baru yang sedang berbulan madu dengan fasilitas khusus dan tersendiri demi kenikmatan perjalanan.
Kualitas objek daya tarik wisata merupakan hal yang penting dalam pariwisata. Mutu objek daya tarik wisata yang baik akan berdampak pada wisatawan.

\section{METODE PENELITIAN}

Kegiatan penelitian merupakan salah satu cara ilmiah guna mendapatkan data untuk suatu tujuan dan manfaat tertentu yang dilakukan secara sistematis dalam waktu yang lama dengan metode ilmiah serta aturan-aturan yang berlaku. Pada metode penelitian tentunya selalu terkait dengan teknik pengumpulan data yang bersifat akurat dan valid untuk digunakan sebagai sumber acuan. Metode pada suatu penelitian sangatlah penting kegunaannya guna mempermudah peneliti dalam melakukan tujuan dari pelaksanaan penelitian.

Menurut Mulyadi (2014: 5) "Penelitian adalah suatu usaha untuk menemukan, mengembangkan, menguji kebenaran dan mencari kembali suatu pengetahuan dengan menggunakan metode-metode ilmiah".

Menurut Nasution dan Usman dalam Mulyadi (2014: 8) "Penelitian adalah proses mendapatkan solusi dari permasalahan setelah melakukan studi dan analisis dari berbagai faktor".

Menurut Sugiyono dalam Mulyadi (2014: 8) penelitian memiliki beberapa ciri, yaitu: Rasional. Yang berarti kegiatan penelitian dilakukan dengan cara-cara yang masuk akal sehingga terjangkau penalaran manusia; Empiris. Yang memiliki arti bahwa kegiatan penelitian itu merupakan caracara yang digunakan dalam penelitian itu teramati oleh indra manusia, sehingga orang lain dapat mengamati dan mengetahui caracara yang akan digunakan; dan Sistematis. Memiliki arti mengikuti prosedur atau langkah-langkah tertentu yang bersifat logis.

Menurut Imam Gunawan (2015: 79) "Penelitian adalah proses yang digunakan untuk mengumpulkan dan menganalisis 
informasi guna meningkatkan pemahaman kita pada suatu topik. Metode penelitian secara umum diartikan sebagai suatu kegiatan ilmiah yang dilakukan secara bertahap dimulai dengan menentukan topik, mengumpulkan data dan menganalisis data, pada akhirnya akan diperoleh suatu pemahaman dan pengertian".

Penelitian kualitatif adalah prosedur penelitian yang menghasilkan data deskriptif berupa kata-kata tertulis atau lisan dari orang-orang dan berperilaku yang dapat diamati yang diarahkan pada latar dan individu secara holistik (utuh). Untuk itu, tidak diperbolehkan mengisolasikan individu atau organisasi ke dalam variabel atau hipotesis, tetapi memandang sebagai bagian dari suatu keutuhan.

Moleong (2011: 6) menyatakan bahwa Penelitian kualitatif adalah penelitian yang bermaksud untuk memahami fenomena tentang apa yang dialami oleh subjek penelitian misalnya perilaku, persepsi, motivasi, tindakan, dan lain-lain, dan secara holistic dan dengan cara deskripsi dalam bentuk kata-kata dan bahasa, pada suatu konteks khusus yang alamiah dan dengan memanfaatkan berbagai metode alamiah.

Menurut Atherton dan Klemmack dalam Soehartono (2011: 35) "Penelitian deskriptif adalah penelitian yang bertujuan untuk memberikan gambaran tentang suatu masyarakat atau suatu kelompok orang tertentu atau gambaran tentang suatu gejala atau hubungan antara dua gejala atau lebih. Dan biasanya penelitian deskriptif ini menggunakan metode survei".

Ibrahim (2015: 59) menjelaskan bahwa metode deskriptif adalah penelitian yang dimaksudkan untuk melukiskan, menggambarkan, atau memaparkan keadaan objek yang diteliti sebagaimana apa adanya, sesuai dengan situasi dan kondisi ketika penelitian tersebut dilakukan.

Seiring dengan teknik yang digunakan dalam penelitian ini adalah penelitian kualitatif dengan metode deskriptif, penelitian ini dilakukan dengan pendekatan induktif karena cara yang digunakan untuk meneliti berangkat dari masalah-masalah bersifat empiris untuk pemecahan masalah yang menyeluruh. Menurut Jujun S. Sumantri dalam Mardalis (2010: 21) menyatakan bahwa cara berpikir induktif berpijak pada fakta-fakta yang bersifat khusus, kemudian diteliti dan akhirnya ditemui pemecahan persoalan yang bersifat umum.

Pendekatan induktif dapat diartikan sebagai suatu prosedur yang tersusun secara sistematis dalam menganalisis data kualitatif serta sebagai suatu upaya yang dilakukan dengan penekanan pada melakukan pengamatan terlebih dahulu terhadap suatu objek tertentu dan kemudian melakukan analisis dan simpulan dari pengamatan yang telah dilakukan tersebut.

Jadi dalam hal ini peneliti melakukan pengamatan pada suatu objek yang diteliti dengan menyatakan suatu pernyataan yang bersifat khusus dan kemudian menarik simpulan yang bersifat umum berdasarkan pernyataan-pernyataan yang bersifat khusus tersebut.

Metode deskriptif induktif dapat disimpulkan sebagai suatu metode penelitian untuk menyelidiki keadaan, kondisi atau halhal lain yang bersifat khusus di lapangan kemudian diteliti dan akhirnya ditemukan pemecahan masalah yang bersifat umum dari fakta-fakta yang bersifat khusus.

Penelitian dilakukan di Kabupaten Pangandaran, khususnya di beberapa kecamatan yang menjadi lokasi destinasi wisata di Pangandaran. Misalnya Kecamatan Sidamulih dan Pangandaran itu sendiri.

\section{HASIL DAN PEMBAHASAN}

Bagaimana Pangandaran menjadi tujuan wisata dunia dan potensi apa yang dimiliki oleh Pangandaran untuk dapat dijadikan destinasi wisata berkelas dunia? 
Pangandaran memiliki berbagai persyaratan yang memenuhi untuk dapat dikembangkan dan ditingkatkan menjadi destinasi wisata berkelas dunia, di antaranya Pangandaran memiliki hal-hal berikut.

1. Pantai yang indah dan memesona, di mana dapat melihat sunrise dan sunset, pada pagi hari di pantai sebelah timur dapat dilihat dan menikmati sunrise setiap pagi, keindahan sang mentari saat bangkit dari tempatnya beradu.

Panorama sunrise di pantai Pangandaran begitu wonderfull dengan sebuah bola bulat yang muncul membawa aura jingga dan menyebarkan sinarnya pada setiap celah saat bersembunyi di balik gundukan awan.

2. Wisatawan dapat menikmati sunset di sisi barat pantai Pangandaran,keindahan sunset ini tidak kalah dengan sunrise yang ada di pantai timur. Panorama sunset ini begitu indah dengan deburan ombak disertai sang mentari yang tengah melambai berpamitan untuk menyingsir membawa malam datang.

3. Wisatawan dapat berenang dan juga berjemur dengan sinar matahari yang hangat di sepanjang sisi pantainya. Bagi wisatawan yang menyukai olahraga pantai seperti surfing dan snorkeling, Pangandaran juga tempatnya. Ombak pantai Batukaras yang bagus yang letaknya tidak jauh dari pantai Pangandaran dapat memberikan tantangan untuk wisatawan yang akan bermain surfing. Sedangkan di Pasirputih wisatawan dapat melakukan snorkeling,perairan yang dangkal dan airnya yang jernih memungkinkan wisatawan untuk melihat hingga ke dasar dan mengamati biota laut seperti kuda laut, bintang laut, tripang, tiram dan ikan yang ada di sana.
Selain keindahan pantainya, Pangandaran juga menyajikan keindahan wisata alam lainnya. Wisatawan yang merindukan kesejukan udara alam, Pangandaran memilikinya. Citumang misalnya, Objek wisata Citumang tidak hanya dikunjungi oleh wisatawan lokal tetapi juga telah banyak di kunjungi wisatawan dari mancanegara sehingga kini namanya menjadi Green Valley Citumang agar lebih mendunia. Citumang merupakan sebuah aliran sungai yang membelah hutan dengan debit aliran sedang yang menuju ke sebuah goa.

Jika diperhatikan wisata Citumang ini begitu memesona, keindahan alam sekitar sungai begitu asri dengan tumbuhan hutan yang masih dapat dinikmati. Tidak hanya itu Citumang juga menawarkan wisata air body rafting di mana wisatawan dapat berenang menyusuri beningnya air sungai menggunakan rompi pelampung dengan durasi 3-4 jam. Selain kejernihan air sungai Citumang juga menjadi daya tarik tersendiri bagi para wisatawan. Selain Citumang, Pangandaran juga memiliki wisata alam lain seperti Green Canyon, Jojogan, Pepedan Hills dan lain sebagainya.

Selanjutnya, bagi wisatawan yang senang dengan kuliner, Pangandaran menyajikan berbagai kuliner ciri khasnya. Misalnya pindang gunung makanan khas Pangandaran, sejenis sop ikan yang mempunyai bumbu yang khas. Biasanya ikan kakap/ikan mangmung/kakap merah/tongkol dan carwang dengan resep tradisional. Pindang gunung menggunakan kepala ikan. Campuran bumbunya adalah jahe, kunyit, bawang merah, bawang putih, daun kedondong muda, honje, dan kencur. Rasanya ada campuran antara asam, pedas dan gurih.

Selain itu, Pangandaran juga memiliki berbagai makan khas lainnya seperti 
makanan seafood. Jadi jika wisatawan yang gemar masakan seafood, tidak ada salahnya untuk mencoba aneka menu masakan yang berbahan dasar dari hewan laut ini mulai dari udang, ikan bawal, cumi hingga kepiting segar yang siap diolah untuk dijadikan makanan lezat, di Pantai Pangandaran Makanan seafood dijual di restoran-restoran di sepanjang pantai timur.

Dengan pesona yang dimiliki Pangandaran, tidaklah mengherankan jika Pangandaran di kunjungi jutaan wisatawan setiap tahunnya. Banyak di antara mereka, sepulang liburan di Pangandaran, mendapatkan pengalaman unik. Keunikan alam dan sumber daya yang dimiliki Kabupaten Pangandaran, merupakan suatu potensi daerah, yang dapat dikembangkan dan ditingkatkan guna menjadikan Pangandaran destinasi berkelas dunia.

\section{SIMPULAN}

Berdasarkan hasil dan bahasan tersebut dapat disimpulkan sebagai berikut.

1. Salah satu masalah utama yang sering dihadapi industri pariwisata, pada umumnya adalah rendahnya aksesibilitas terhadap berbagai sumber produktif termasuk informasi dan pelayanan teknologi. Hal ini berimplikasi pada pemborosan penggunaan seluruh sumber daya yang ada dan dapat menimbulkan kerancuan. Bahkan kebingungan di antara industri pariwisata sendiri atas program pembinaan yang ada. Oleh karena itu, upaya percepatan peningkatan aksesibilitas industri pariwisata terhadap sumber daya produktif, termasuk pelayanan informasi, dan teknologi, sangat penting untuk segera di wujudkan.
2. Sektor pariwisata merupakan sektor tersier di mana preferensi wisatawan sangat ditentukan oleh tingkat kenyamanan, maka dukungan sarana dan prasarana untuk meningkatkan aksesibilitas ke lokasi objek wisata mutlak dibutuhkan. Pengembangan jaringan transportasi, wilayah, dan lokal untuk mendukung pengembangan pariwisata.

3. Meningkatkan kualitas dan kuantitas sumber daya manusia sebagai pelaku kebijakan dalam bidang kepariwisataan melalui jenjang pendidikan yang bersifat formal maupun nonformal. Sehubungan dengan hal tersebut, maka sistem dan mekanisme pendidikan dan latihan (diklat) perlu di desain secara baik, sehingga dapat menjawab tantangan kebutuhan pada masa yang akan datang, khususnya tuntutan menciptakan aparatur yang memiliki keunggulan kompetitif, bersih dan berwibawa, handal serta efektif dan efisien.

4. Mengembangkan kemitraan dengan lembaga pendanaan (bank maupun nonbank) baik lembaga pemerintah maupun swasta untuk menciptakan investasi baru dalam rangka mengembangkan daerah tujuan wisata.

5. Untuk mencapai keberhasilan pengembangan kegiatan pariwisata, harus dilakukan secara koordinatif dan terpadu antarsemua pihak yang terkait sehingga terwujud keterpaduan lintas sektoral dan menghindari terjadinya konflik antarsektor. Peningkatan keterkaitan fungsi pengembangan kegiatan pariwisata yang baik dengan sektor lainnya untuk memberikan nilai efisiensi yang tinggi dan percepatan pertumbuhan ekonomi wilayah. Pengembangan pariwisata harus dikaitkan dengan pengembangan ekonomi daerah. 


\section{SARAN}

Untuk mewujudkan destinasi wisata Pangandaran menjadi wisata berkelas dunia, diperlukan adanya:

1. Penyempurnaan aksesibilitas jalan darat, dari Kota Banjar ke Kabupaten Pangandaran;

2. Perlu adanya bandara yang bertaraf internasional, bandara yang ada saat ini, masih bersifat bandara perintis antarpulau;

3. Perlu dilakukan adanya penataan pada lokasi usaha mikro kecil dan menengah (UMKM), di kawasan wisata, baik yang ada di kecamatan-kecamatan yang menjadi destinasi wisata, maupun di pantai Pangandaran;

4. Perlu dilakukan adanya sosialisasi kepada masyarakat, terkait destinasi wisata berkelas dunia, agar masyarakat dapat menyesuaikan dengan kondisi budaya yang ada di Pangandaran, dalam arti budaya lokal, atau kearifan lokal harus tetap dipartahankan, dengan masuknya budaya asing ke Pangandaran, agar pengunjung merasakan kekagumannya dan amat terkesan;

5. Untuk pengunjung destinasi wisata, merasa aman dan nyaman berkunjung ke destinasi pariwisata di Pangandaran, perlu adanya pengawasan dan ketertiban agar wisatawan merasakan kenyamanan dengan kondisi yang kondusif.

\section{DAFTAR RUJUKAN}

BPS. 2018. Perkembangan Pariwisata dan Transportasi Nasional Desember 2017. [internet]. [diunduh 2018 September 20]. Tersedia Pada: https://www.bps. go.id

Kementerian Pariwisata. 2015b. Peningkatan devisa sektor pariwisata. [internet]. [diunduh 2018 Juni 7]. Tersedia pada: http://www.kemenpar.go.id

Moleong, Lexy J. 2011. Metodologi Penelitian Kualitatif. Bandung: PT Remaja Rosdakarya.

Creswell, John W. 2014. Penelitian Kualitatif dan Desain Riset, edisi Ketiga. PT Pustaka Pelajar.

Sugiyono. 2014. Memahami Penelitian Kualitatif. Bandung: Alfabeta.

Yoeti, Oka A. 2014. Pengantar Ilmu Pariwisata. Bandung: PT Angkasa

Sedarmayanti. 2014. Membangun dan Mengembangkan Kebudayaan dan Industri Pariwisata. Bandung: PT Refika Aditama

Pitana, I Gede dan Suryadinata, I Ketut. 2009. Pengantar ilmu Pariwisata. Yogyakarta: ANDI.

Undang-Undang No. 10 Tahun 2009 tentang Kepariwisataan

Undang-Undang No. 23 Tahun 2014 tentang Pemerintahan Daerah 